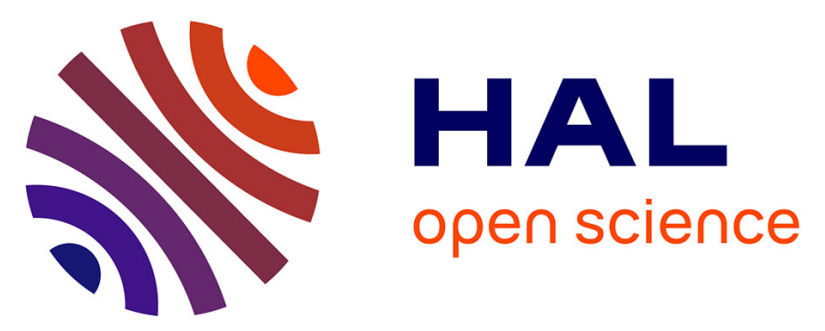

\title{
Pre-Eocene Synmetamorphic Structure in the Mindoro-Romblon-Palawan Area, West Philippines, and implications for the history of southeast Asia
}

Michel Faure, Yves Marchadier, Claude Rangin

\section{To cite this version:}

Michel Faure, Yves Marchadier, Claude Rangin. Pre-Eocene Synmetamorphic Structure in the Mindoro-Romblon-Palawan Area, West Philippines, and implications for the history of southeast Asia. Tectonics, 1989, 8 (5), pp.963-979. 10.1029/TC008i005p00963 . insu-00716213

\section{HAL Id: insu-00716213 \\ https://hal-insu.archives-ouvertes.fr/insu-00716213}

Submitted on 10 Jul 2012

HAL is a multi-disciplinary open access archive for the deposit and dissemination of scientific research documents, whether they are published or not. The documents may come from teaching and research institutions in France or abroad, or from public or private research centers.
L'archive ouverte pluridisciplinaire $\mathbf{H A L}$, est destinée au dépôt et à la diffusion de documents scientifiques de niveau recherche, publiés ou non, émanant des établissements d'enseignement et de recherche français ou étrangers, des laboratoires publics ou privés. 
TECTONICS, VOL. 8, NO. 5, PAGES 963-979, OCTOBER 1989

PRE-EOCENE SYNMETAMORPHIC STRUCTURE IN THE MINDORO-ROMBLON-PALAWAN AREA, WEST PHILIPPINES, AND TMPLICATIONS FOR THE HISTORY OF SOUTHEAST ASIA

Michel Faure

Départment des Sciences de 1a Terre, Université d'Orléans, Orléans, France.

Yves Marchadier and Claude Rangin

Département de Géotectonique, Université Pierre et Marie Curie, Paris, France.

Abstract. The structure of the pre-Eocene rocks, considered as the "basement" of the Philippines, has been investigated in the Mindoro-Lubang, Romblon-Tablas-Sibuyan, and North Palawan areas. In the former two areas the same pre-Eocene succession of units is recognized from top to bottom: (1) a pre-Eocene olistostrome; (2) an ophiolitic nappe; (3) a schistose sequence (pelites, sandstones, basic schists and marbles); and (4) a gneissic unit. The nature of the contact between the olistostrome and the underlying units is unclear, but the ophiolite and the schistose sequence form two thrust sheets of oceanic origin thrust upon the gneissic unit that is considered a part of a continental basement called the West Philippines Block. Small-scale structures show that the early deformation stage is characterized by a submeridian $\left(0^{\circ}-\mathrm{N} 40^{\circ} \mathrm{E}\right)$ lineation formed in greenschist to amphibolite facies conditions during the thrusting. Kinematic analysis show that the thrusting was from north to south. In North Palawan, metamorphic rocks with similar microtectonic and kinematic characteristics are found. They are overlain by a Late Jurassic olistostrome

Copyright 1989

by the American Geophysical Union.

Paper number $89 \mathrm{TC} 00709$.

0278/7407/89/89TC-00709\$10.00 which is correlated with the olistostromes found in Calamian, North Mindoro, Carabao, and Buruanga peninsula (North Panay). The microstructural features and the presence of the olistostrome suggest that the North Palawan, Mindoro, Tablas, Romblon, Sibuyan, and Carabao islands belong to the same North Palawan block of Hamilton (1979) which is a continental fragment rifted from Asia in Cenozoic times. It is assumed that the Western Panay and Zamboanga areas, which are characterized by Mesozoic ophiolites and metamorphic rocks, also belong to the North Palawan Block. A11 these islands experienced, to some extent, the same Mesozoic geohistory: the south verging thrusting is interpreted as the result of an oblique collision of the West Philippines Block with Asia. The contemporaneous left-lateral strike-slip faulting and the calc-alkaline magmatism widespread along the Chinese margin are also included in the geodynamic model.

\section{INTRODUCTION}

The Philippine Islands lay at the convergent boundary between the Eurasian margin and the Philippine Sea plate. From Taiwan to the Celebes Sea several domains can be distinguished (Figure 1), namely, (1) a collision area in Taiwan between eastern Asia and the northern end of the Luzon arc, (2) an oceanic subduction area 
in the South China Sea west of the Luzon arc along the Manila trench, (3) a complex collision area with transcurrent motion, between the islands of Palawan on one hand and Mindoro-Panay on the other hand, (4) an oceanic subduction area of the Sulu Sea below the central Philippines along the Negros trench, and (5) an oceanic subduction area of the Celebes Sea below Mindanao.

The geology of the Palawan-Mindoro area has been studied by many workers (e.g., Hamilton, 1979; Hashimoto, 1981; Holloway, 1982; McCabe et a1., 1982, 1985; Taylor and Hayes, 1983; Karig, 1983; Rangin et a1., 1985; Stephan et al., 1986; Mitchell et al., 1986; Sarewitz and Karig, 1986; Marchadier, 1988). According to their conclusion, the structure of this area is the result of a collision of the Palawan microcontinent with an eastern microblock called the East Mindoro Block. The former microcontinent includes, in addition to the northern part of Palawan, the Calamian Islands, the western part of Mindoro, and the Buruanga peninsula in western Panay (Figure 1). It was rifted from SE China in 0ligocene-early Miocene times when the South China Sea opened. The East Mindoro Block includes, at least, eastern Mindoro, Lubang, Golo, and Ambil Islands (Figure 2 ). The eastern 1imit of this block is unclear. The origin of the East Mindoro block is also disputed. For Karig (1983), McCabe et al. (1982, 1985), Mitchell et a1. (1986), and Sarewitz and Karig (1986) it is an "allochtonous terrane" traveling from some remote southern region. For Hashimoto (1981), Holloway (1982), Rangin et al. (1985), and Marchadier (1988), the East Mindoro Block is a small piece of the Palawan microcontinent which has been slight1y pulled apart in 01igocene times from the main part of the Palawan microcontinent and rewelded during Middle Miocene times.

Pre-Tertiary rocks have been recognized for a long time in the central Philippines (e. g., Irving, 1950; Gervasio, 1967; Bureau of Mines, 1963). These metamorphic rocks present1y form three geographic groups: (1) the Palawan metamorphics found in North Palawan and Calamian; (2) the Mindoro metamorphics found in East Mindoro, Lubang, Golo, and Ambil; and (3) the Romblon metamorphics found in Tablas, Romblon, Sibuyan, Carabao, and Panay (Figures 1 and 2). These basement rocks are composite. Some are real1y metamorphosed while some are only weakly transformed or virtual1y unmetamorphosed.

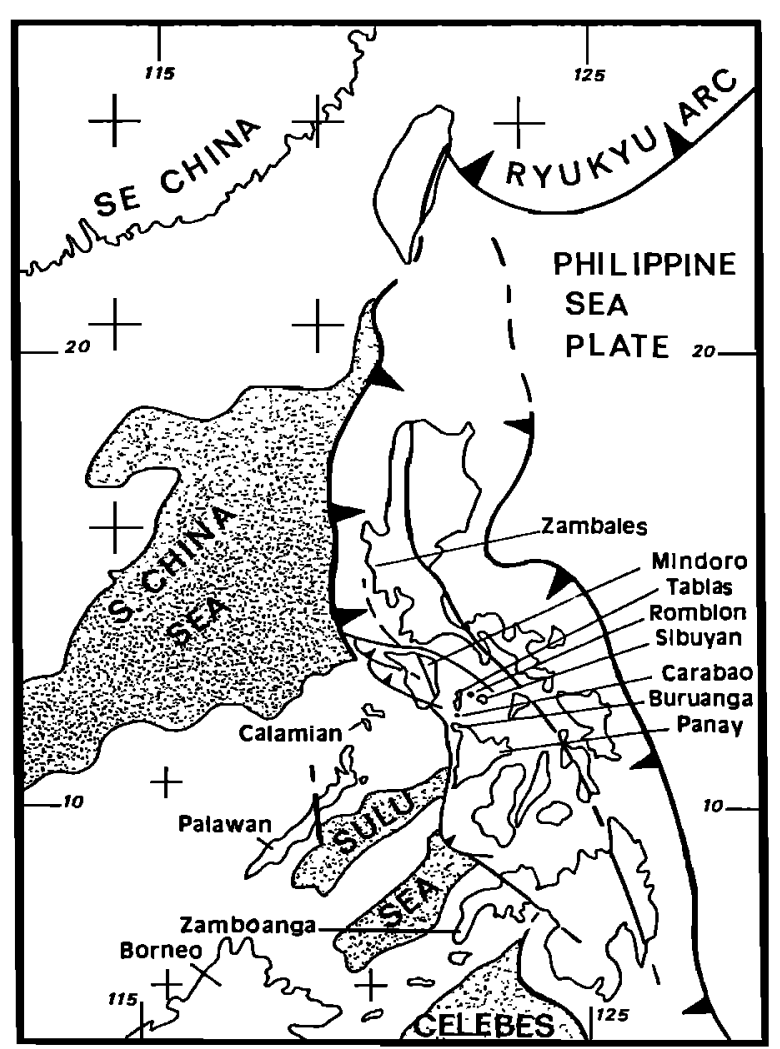

Fig. 1. Present geodynamic framework of the Philippine archipelago. The dot pattern in the marginal seas stands for oceanic crust.

Because of the complex Cenozoic geodynamic evolution of the region, the correlations between each group are not settled. This paper deals with the tectonics of the Mindoro, Romblon, and Palawan metamorphics. The regional structure, deformation stages, and synmetamorphic kinematics are described, and a correlation is proposed. Assuming that these pre-Eocene rocks belong to the Palawan block, a geodynamic mode1 accounting for the pre-South China Sea geohistory of Southeast Asia is discussed.

\section{THE MINDORO METAMORPHICS}

The Mindoro metamorphics form the backbone of the island, culminating in Mt. Halcon (Irving, 1950; Teves, 1953; Hashimoto and Sato, 1968). These rocks are well exposed on the north coast of Mindoro. Though separated by strike-slip faults (Figure 3 ), the metamorphics outcropping in the islands of Lubang, Golo, and Ambil belong also to the same group. 


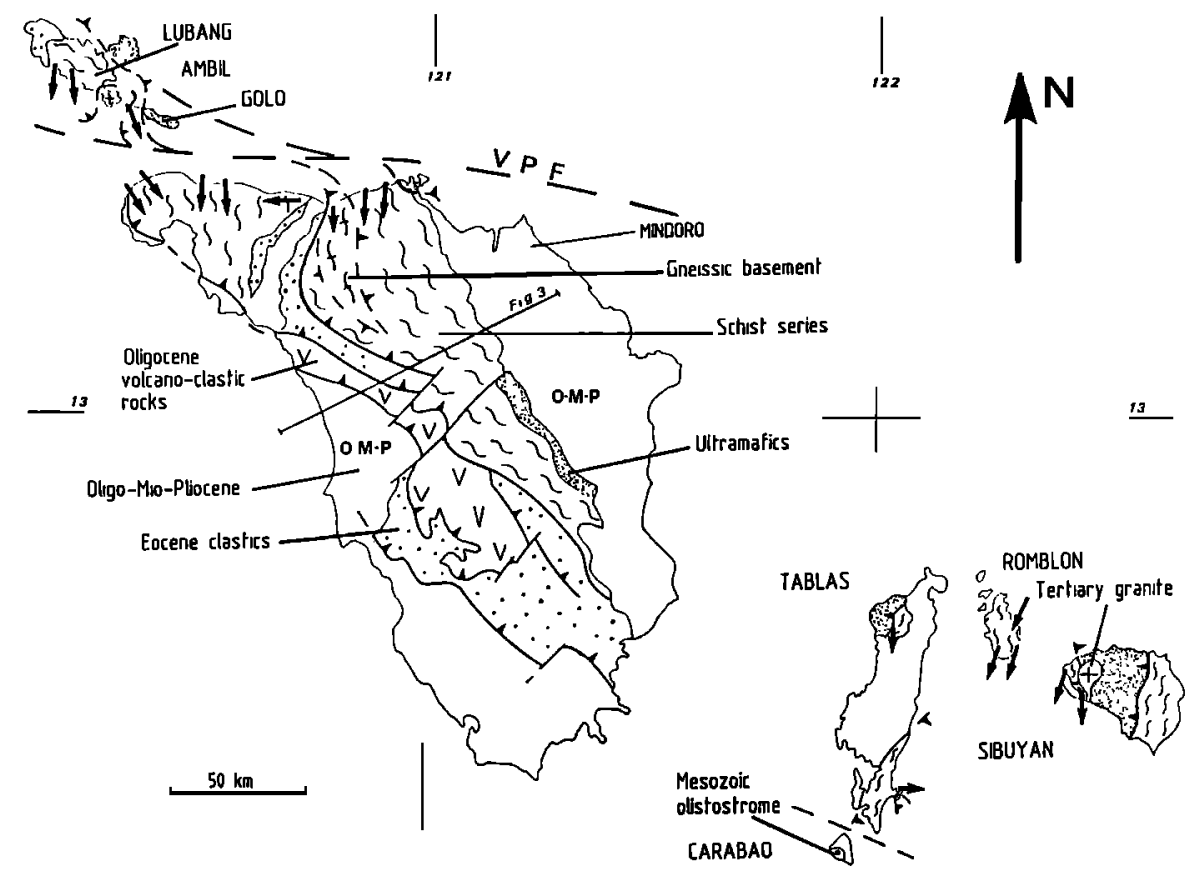

Fig. 2. Structural map of the Mindoro-Lubang and Romblon-Tablas areas. VPF, Verde Passage fault. Arrows represent average stretching lineation trends, with shear sense of the upper block with respect to the lower block. Simplified from Bureau of Mines (1963).

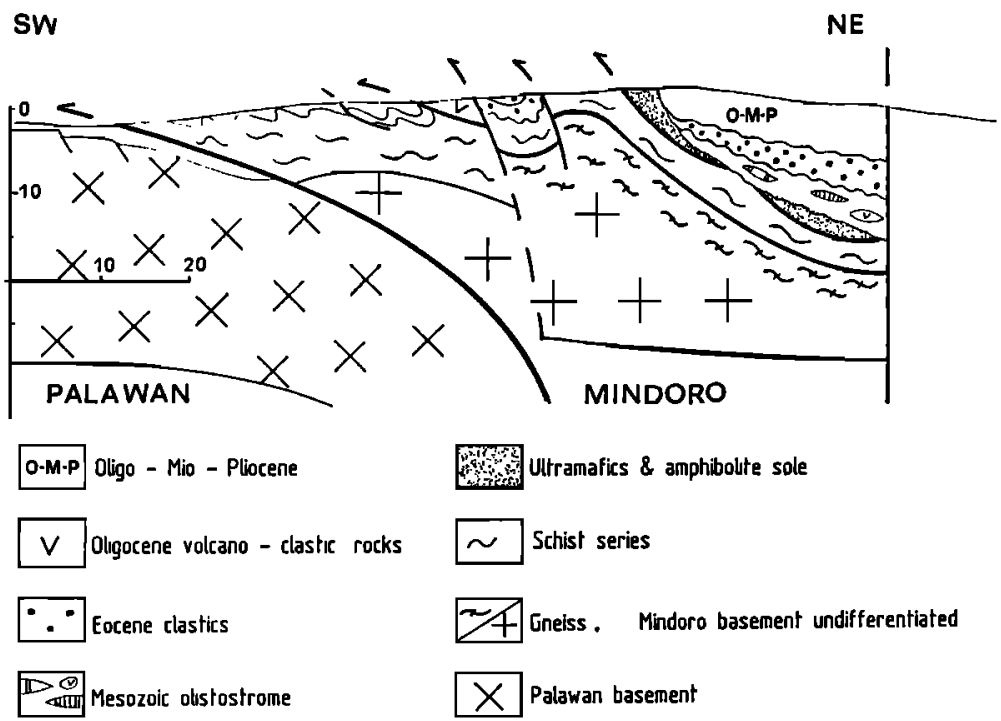

Fig. 3. Present crustal-scale interpretative cross section of Mindoro.

\section{Lithology and Age}

Four lithologic groups are distinguished from top to bottom: (1) olistostrome with chert blocks poorly exposed near Puerto Galera, (2) serpentinized ultramafics (mainly harzburgite) found in Puerto Galera, Golo, and Ambil Islands (Caagusan, 1966; Andal and Caagusan, 1968; Karig, 1983; Malicse and Yumul, 1986; McCabe et al., 1985) (they are not studied here) (3) a 
sedimentary sequence formed by pelitic schists, metasandstone, and basic schists: volcanoclastites, gabbroic sandstone, and breccia, other facies such as metachert and marble are also found, and the association of terrigenous sediments together with chert and basic schists (indicating a kind of ophiolitic detritism) suggests that they formed in an active margin environment, (4) a gneissic sequence outcropping in Mindoro, along the Odalo river, (Caagusan, 1966) and in east Lubang and west Golo (unreported until now). Several gneissic facies are recognized: arkosic or acid volcano-detrital rocks, biotite bearing paragneisses, orthogneisses (metagranodiorite) crosscut by leucocratic gneisses (probably dykes), and metadioritic gneiss and xenolithic schists. There is no radiometric data, but a reasonable interpretation is to consider the gneisses as a sialic basement formed by magmatic rocks and a sedimentary cover.

The Mindoro metamorphics lack fossils or isotopic data, and hence the age is unknown. Caculitan et a1. (1978) assume that they are Jurassic or Cretaceous. On the basis of Sr isotopic composition of the marbles, Knittel and Daniels (1987) have proposed an early Paleozoic age for the protolith, though according to their own data a late Paleozoic age ranging between middle Carboniferous to ear1y Permian seems more likely in agreement with the geological environment. Recent KAr datings on hornblende separates from amphibolite and garnet amphibolite rocks from Mindoro indicate a $59 \mathrm{Ma}$ age of metamorphism ( $R$. McCabe, written communication, 1989). According to Karig (1983) and Sarewitz and Karig (1986), upper Cretaceous basalts overlay the Mindoro metamorphics. However, the contact is never observed, and the precise fauna list is not given. It is often argued that the Mindoro metamorphics are of Paleozoic or at least pre-late Jurassic age (e.g., Hashimoto and Sato, 1968; Hashimoto, 1981) because they are unconformably overlain by the Mansalay formation which is a turbiditic sequence with intraformationnal conglomeratebearing pebbles of crystalline schists and Callovian-0xfordian ammonites (Sato, 1961; Andal et al., 1968). However, objections arise, first, the unconformity is unclear and second, micropaleontological studies (Marchadier, 1988) indicate an Eocene age for most of the Mansalay formation. The Mesozoic fossils are probably reworked either in themselves or together with their surrounding rocks as olistoliths. Therefore the unconformity, if real, is probably younger than Mesozoic. Moreover, as the main outcrops of the Mansalay formation lay on west Mindoro, the metamorphic pebbles might also derive from the Palawan metamorphics.

The Mindoro metamorphics are undoubtedly unconformably covered by hemipelagic siltites and sandstones (the Lasala formation) of middle Eocene age (Hashimoto, 1981; Sarewitz and Karig, 1986; Marchadier, 1988). As already noticed (Karig, 1983; Sarewitz and Karig, 1986) there is a metamorphic and structural gap between the well-foliated basement and the Eocene cover, which is affected only by a slaty cleavage. In western Lubang (at Binacas) we found a reef limestone containing the following foramminifera: Pellatispira mirabillis (Umbgrove), Operculina cf. saipanensis, Amphistegina radiata, Rotalidae sp., and Spherogypsina sp. determined by $\mathrm{J}$. Butterlin (Marchadier, 1988) to be of late Eocene age. In conclusion the Mindoro metamorphics are not younger than Eocene and probably not older than late Paleozoic.

\section{Regional Structures}

The structures are obviously due to a polyphase deformation. In the Calavite area (Figure 4) the metamorphic rocks overthrust Eocene slates (Rangin et a1., 1985). In the slates the slaty cleavage bears an E-W trending mineral lineation of phyllites and a stretching lineation of pu11-apart and elongated clasts in pebbly mudstones, which is in agreement with the 0ligo-Miocene tectonics. The kinematics of this phase have not been studied.

In addition to these Cenozoic structures, two ductile deformation phases affect the metamorphic rocks. The second one is responsible for kilometer scale upright antiforms (Figures 2, 4, and 5). They trend close to N-S in Central Mindoro and Wawa area, and they are deflected to the WNW-ESE trend in Lubang (Caagusan, 1966; Hashimoto and Sato, 1968) by the left-lateral Lubang fault (Marchadier, 1988). At the meter scale the foliation (S1) is microfolded and cut by a 


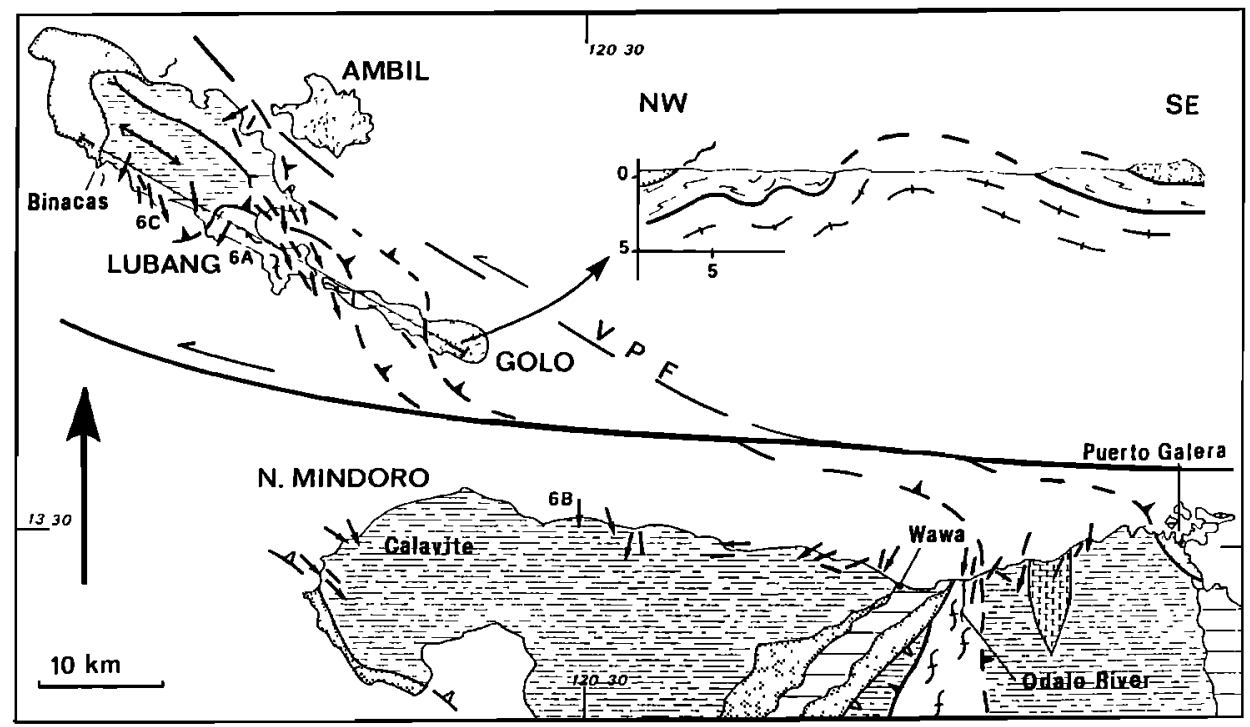

Oligo-Mio-Pliocene
$\therefore$ Mesozoic olistostrome
$\begin{aligned} & \text { Stretching lineation with Shear sense } \\ & \text { antiform } \\ & \text { synform }\end{aligned}$

Fig. 4. Lineation map and cross section of the North Mindoro-Lubang area. Arrows represent average stretching lineation trends, with shear sense of the upper block with respects to the lower block. Simplified from Bureau of Mines (1963). Numbers 6A, 6B, and 6C are the locations of Figure 6 photographs.

discrete crenulation cleavage (S2) which is axial planar to parasitic minor folds associated with the large-scale antiforms. Along the S2 surfaces, opposite offsets and curvature of $S 1$ are observed on both 1 imbs of the fold. The apparent

displacement is to the north in Lubang and to the south in Calavite. Shear criteria such as pressure shadows are lacking, it is likely that the offsets are mainly apparent due to volume change caused by flattening.

The regional major structure, prior to the folding and faulting events, corresponds to a stack of thrust sheets. Genera11y, the precise contacts are not observed, but they are well exposed on the south coast of Lubang and Golo. The gneissic series are thrust by the schist series which in turn is thrust by the serpentinized peridotite (Figures 2 and 4). A similar thrust of the ultramafics upon the schists is described near Puerto Galera (McCabe et a1., 1985; Malicse and Yumu1, 1986). At the microtectonic scale the thrusting is responsible for the regional foliation S1 observed in every lithology except the granitic core of the antiforms. S1 bears a mineral and stretching lineation L1 which is we11 marked in a11 rocks except some massive marbles and the peridotites. L1 is also refolded by the crenulation folds.

Metamorphism and Kinematics of the First Phase

A cursory examination of the metamorphic minerals present was carried out. In pelitic schists the most common assemblage is quartz, albite, biotite, and garnet; stilpnomelane is conspicuous in gneisses; actinolite and epidote are present in basic schists. As these phases 
belong to the epidote-amphibolite facies, pressure and temperature during the synmetamorphic deformation are estimated around $5 \mathrm{kbar}$ and $450^{\circ}-500^{\circ} \mathrm{C}$, respectively.

As already stated, Ll is a mineral and stretching lineation. In the field it is also marked by cigar-like quartz rods in pelitic schists, biotite streaks in gneisses, and elongated pebbles of conglomerate. The Ll trend (Figures 4 and 5) is dominantly submeridian: NW-SE in Lubang, Golo, and Calavite areas; N-S near Puerto Galera, and E-W west of Wawa. The last trend, mainly found just below the Eocene slate, could be due to a local reorientation when the Eocene rocks were deformed.

The deformation regime has been investigated by looking at the asymmetric structures in sections perpendicular to S1 and parallel to L1 (e.g., Eisbacher, 1970; Etchecopar, 1977; Simpson and Schmid, 1983; Passchier and Simpson, 1986; Cobbold et a1., 1987). The most common criteria are asymmetric pressure shadows (Figures $6 \mathrm{~b}$ and $\mathrm{c}$ ) which are widespread around clasts in sandstone and impure marble. These shadows are also found around metamorphic minerals (albite, garnet) in pelitic schist and around pyrite or epidote in basic schist. Sigmoidal biotite (Figure 6a) are found in gneisses. The quartz $C$ axes preferred orientation have been used also. The senses of shear (Figure 4) along the lineation show a consistent shear from the north toward the south. Assuming that the lineation reflects the nappe transport direction for a shear intensity $(\gamma)$ greater than 5 (e.g., Escher and Watterson, 1974;

Mattauer et al., 1981; Malavieille et al., 1984) the nappe emplacement occurred from north to south. The geodynamic significance of the motion will be discussed below.

\section{THE ROMBLON METAMORPHICS}

East of Mindoro, "basement rocks" are recognized in the islands of Tablas, Romblon, Sibuyan and west Panay (Figures 2 and 3 ). In the following we dea1 only with Tablas, Romblon, and Sibuyan areas. It is sometimes argued (e.g., Karig, 1983; Mitche11 et a1., 1986) that a major strikeslip fault, the "Tablas lineament", separates Tablas and Romblon. On the east coast of Romblon, no microstructure favoring such a fault has been observed.
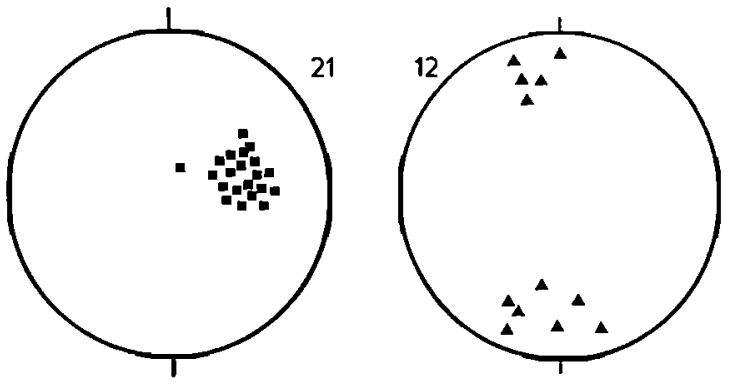

NORTH TABLAS
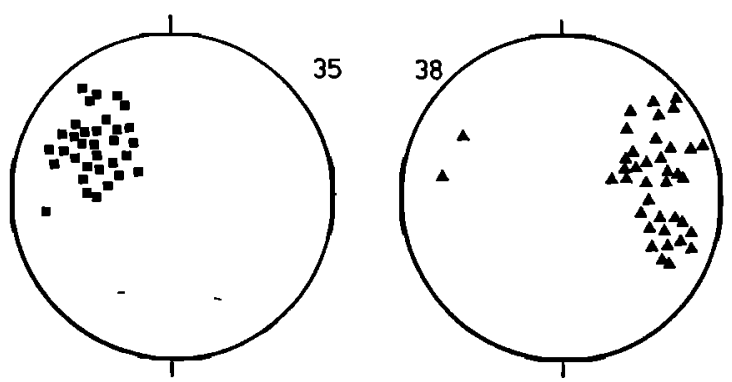

SOUTH TABLAS
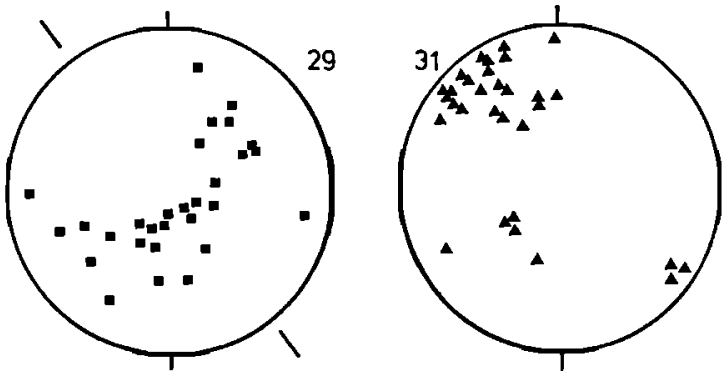

LUBANG
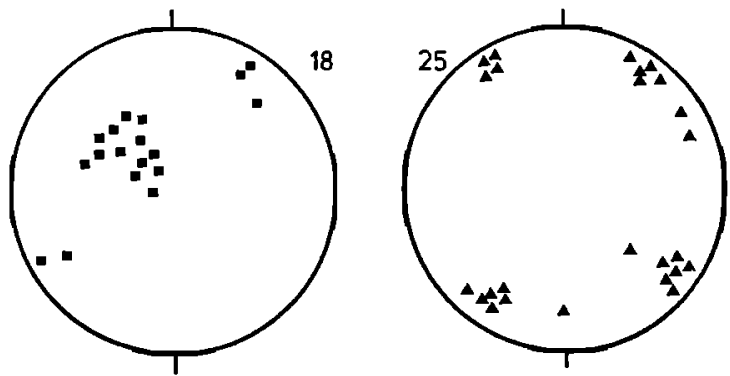

NORTH MINDORO COAST

Fig. 5. Stereographic diagrams of Lubang, North Mindoro coast, and north and south Tablas areas. The squares represent pole projections of foliation planes. The triangles represent the projection of stretching lineations. The $\mathrm{N} 150^{\circ} \mathrm{E}$ trending line on the foliation pole diagram of Lubang is the axis of the upright fold. Numbers of measurements given next to each lower hemisphere projection. 

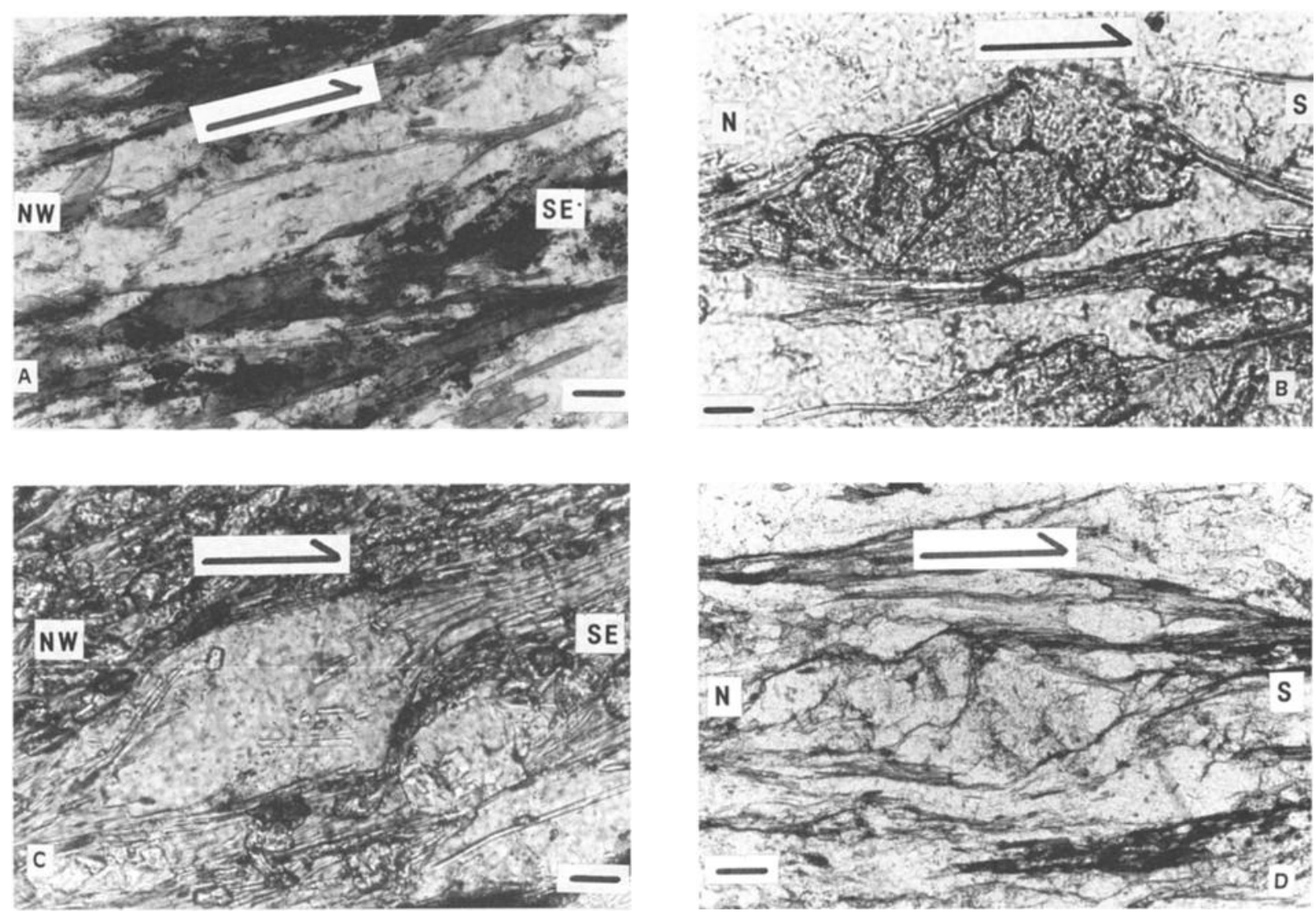

Fig. 6. Microscopic shear criteria in Mindoro-Lubang and Palawan areas.

Scale bar is $0.5 \mathrm{~mm}$. Photo localities are shown on Figures 4 and 10. (a) Sigmoidal muscovite in gneiss, Lubang. (b) Epidote with asymmetric pressure shadows in mafic schist, Mindoro. (c) Clast with asymmetric pressure shadows in pelitic schist, Lubang. (d) Quartz clast with asymmetric biotite pressure shadows, West of Caramay, Palawan.

However, since sea bottom deepens very quickly, such a fault may exist but is of minor importance as far as the basement geology is concerned. The equivalence between the metamorphic rocks of Tablas, Romblon, and Sibuyan can be safely considered as verified by lithologic, metamorphic, and structural similarities. In the following they will be referred to as the Romb1on metamorphics, since these rocks are best exposed on the island of Romblon. In Tablas the metamorphic rocks outcrop only in the north, east, and south areas (Figure 7). The Romblon metamorphics are similar to the Mindoro metamorphics. However, here we discuss the typical features of the Romblon metamorphics separately.

\section{Lithology and Age}

Three series are distinguished from top to bottom, namely, (1) an ophiolitic series underlain by an amphibolite sole common in other ophiolitic overthrusts (e.g. Oman, Newfoundland, etc), (2) a schist series formed by pelitic schists, metasandstone, quartzite, and marble (very abundant in Romblon); several kinds of basic schists: lavas, tuffs, basic siltites, gabbroic sandstones, and conglomerates belong to this series, and (3) a gneissic serles formed by acidic volcaniclastic rocks is found only in Sibuyan. Some weakly or unfoliated granitoids found as float in northern Tablas might belong to this group. 


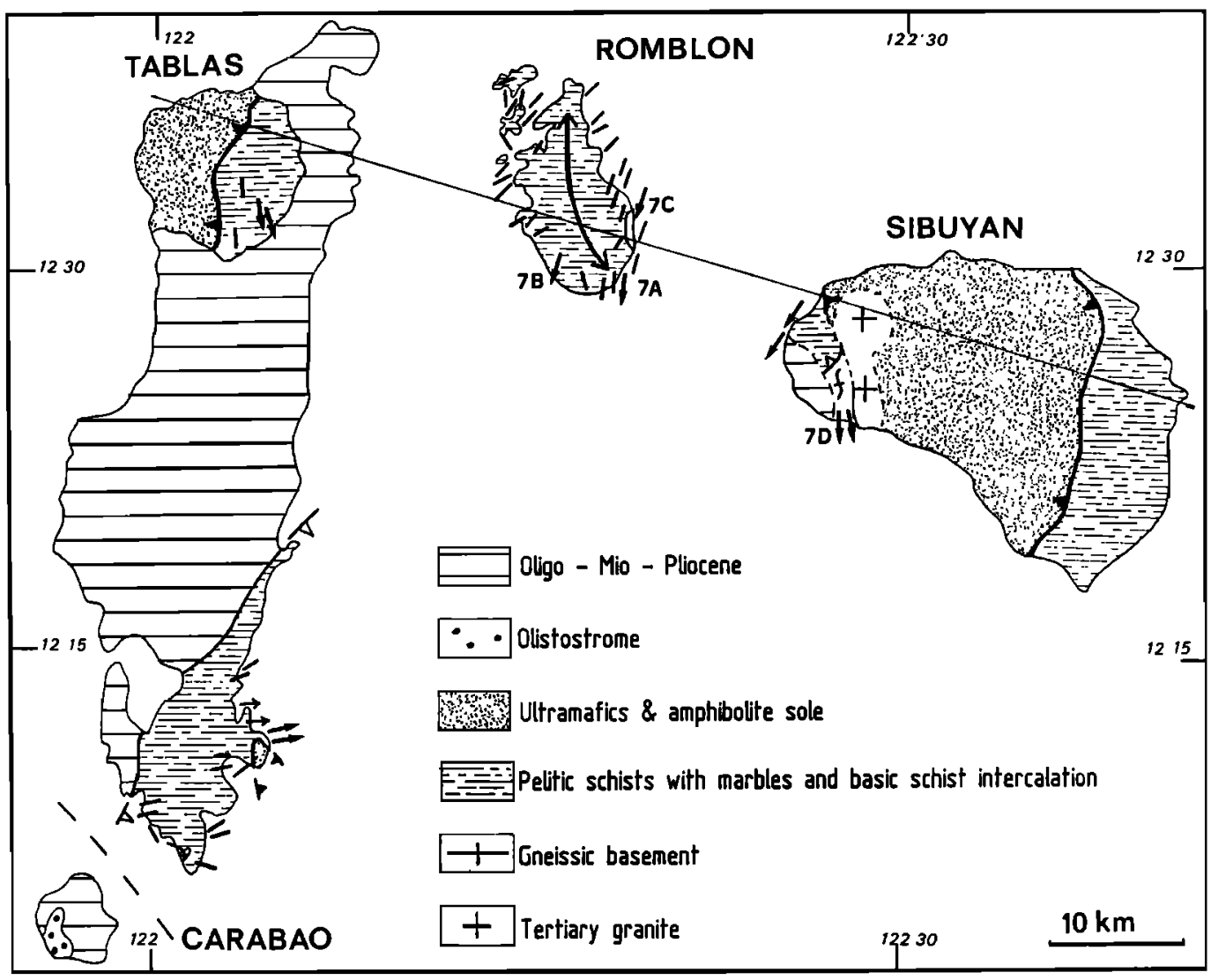

Fig. 7. Lineation map of the Romblon metamorphics. Arrows represent average stretching lineation trends, with shear sense of the upper block with respect to the lower one. Simplified from Bureau of Mines (1963).

However, these rocks could also belong to the Paleogene granites widespread in this area (Metal Mining Agency, 1983). Neither stratigraphic nor radiometric ages are available except the Permian limestone of Carabao island (Andal et al., 1968) which is an olistolith. The only chronological constraint is the 01igocene-early Miocene arc sequence found to unconformably cover the metamorphic rocks in Tablas, Romblon and Sibuyan (Marchadier, 1988). Moreover, the metamorphics are intruded by undeformed granitoids of unknown age in Tablas but supposed to be of Paleocene age in Sibuyan (Metal Mining Agency, 1983).

\section{The Polyphase Deformation}

Only the ductile structures, are considered here, (a discussion of brittle structures is given by Marchadier 1988).
The ductile structures are grouped into two phases. The youngest deformation is responsible for upright folds which are well observed in Romblon and Tablas. Their axes are submeridian in average, with local arcuation (Figure 7). A crenulation cleavage develops which is axial planar of meter and centimeter scale parasitic folds. The first phase regional-scale structure cannot be inferred from one cross section, but from the bulk geometry of the area and correlations between several cross sections one can consider the stack of thrust sheets as the major structure. The ophiolite sequence overthrusts the schist series which in turn overthrusts the gneissic series (Figure 8 ). This main phase occurred in a metamorphic context and is responsible for the regional foliation (S1) and stretching lineation (L1). The lineation trend (Figures 2, 5, and 7) shows that the submeridian 


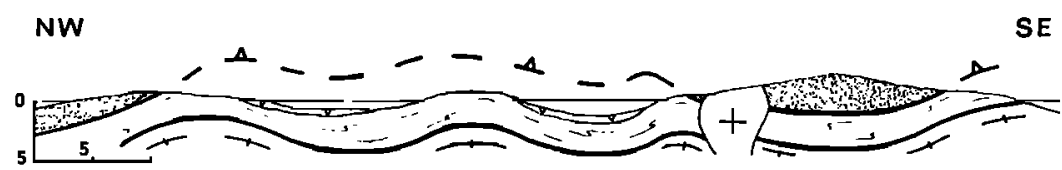

Fig. 8. Interpretative schematic cross section from Tablas to Sibuyan along the line shown in Figure 7 (same symbols).

direction (from NE-SW to NW-SE) is dominant except in east and south Tablas where it is E-W. In southern Tablas a post-Sl thermal event (discussed below) has erased early structures. In Romblon the mineral lineation is strengthened by the axes of isoclinally folded quartz lenses which display sheath fold structures characteristic of non coaxial deformation (e.g., Cobbold and Quinquis, 1980).

\section{Metamorphisms}

The type of metamorphism of Romblon -Sibuyan differs from the metamorphism observed on Tablas. On Romblon-Sibuyan the assemblages of quartz-muscovite-biotite graphite in pelitic schist and actinolitechlorite-epidote in basic schist indicate low-pressure greenschist facies conditions. On Tablas there is a conspicuous thermal event. In south Tablas, though no granitoids have been found except one meter scale dyke, the sandstones and pelites are transformed into biotite hornfelses, suggesting the existence of an underlying mass. In east Tablas, quartz-biotite-garnet-staurolite assemblage is sporadically found in pelitic schists, indicating higher pressure and temperature conditions, about 4-5 kbar and above $550^{\circ} \mathrm{C}$ respectively. The garnet, biotite, and staurolite porphyroblasts have a larger size than the matrix minerals upon which they overprint, as shown by the subautomorph shape of the garnet and the inclusions in staurolite. However, these rocks also experienced a ductile deformation, indicated by the quartz pressure shadows around garnet and biotite or kinked staurolite with folded inclusions. Because of this thermal event, a11 the eventual previous metamorphic assemblages which might have appeared related to the thrust emplacement are erased. In north Tablas the microstructures of the hornblende crystals in the amphibolite sole (e.g., sharp extinction, plane joint boundaries, triple junctions) indicate a post tectonic annealing which is likely related to intrusive rocks that have not been found in the field. Along streams, biotite granite and pegmatite boulders are conspicuous.

Kinematics of the First Phase

Asymmetric quartz lenses or largescale pressure shadows have been used directly in the field as shear indicators. At the microscopic scale the same criteria as those used for the Mindoro metamorphics have been systematica11y employed: asymmetric pressure shadows, sigmoidal phyllosilicates, and quartz $\mathrm{C}$ axis preferred orientation (Figure $9 a$ and 9c).

In south Romblon, $\mathrm{Sl}$ is cut by oblique surfaces, corresponding to a kind of crenulation cleavage, the spacing is between 3 and $10 \mathrm{~mm}$. There is no microfolding of S1 between two shear surfaces, these cleavage zones end by curving and merging with $\mathrm{S} 1$, and there is no obvious chemical differentiation in the cleavage surface (thus the volume is conserved). These lines of evidence show that these bands are smal1-scale shear zones with a normal offset (Figure 9b). These shear bands indicate a real displacement of $S 1$, with extension parallel to L1. The downfaulted block is always the southeast block. Such a microstructure is similar to the extensional crenulation cleavage (Platt and Vissers, 1980) often found near the mylonitized contacts. Though not always unequivocal kinematic indicators, the asymmetry of the Romblon extensional crenulation cleavage is in agreement with a shear directed toward the southeast along the lineation. The differences of the $S 2$ cleavage, in which microfolded S1 surfaces and pressure solution deformation are shown by concentrations of ferromagnesian particles argue against a shear displacement along S2 planes. 

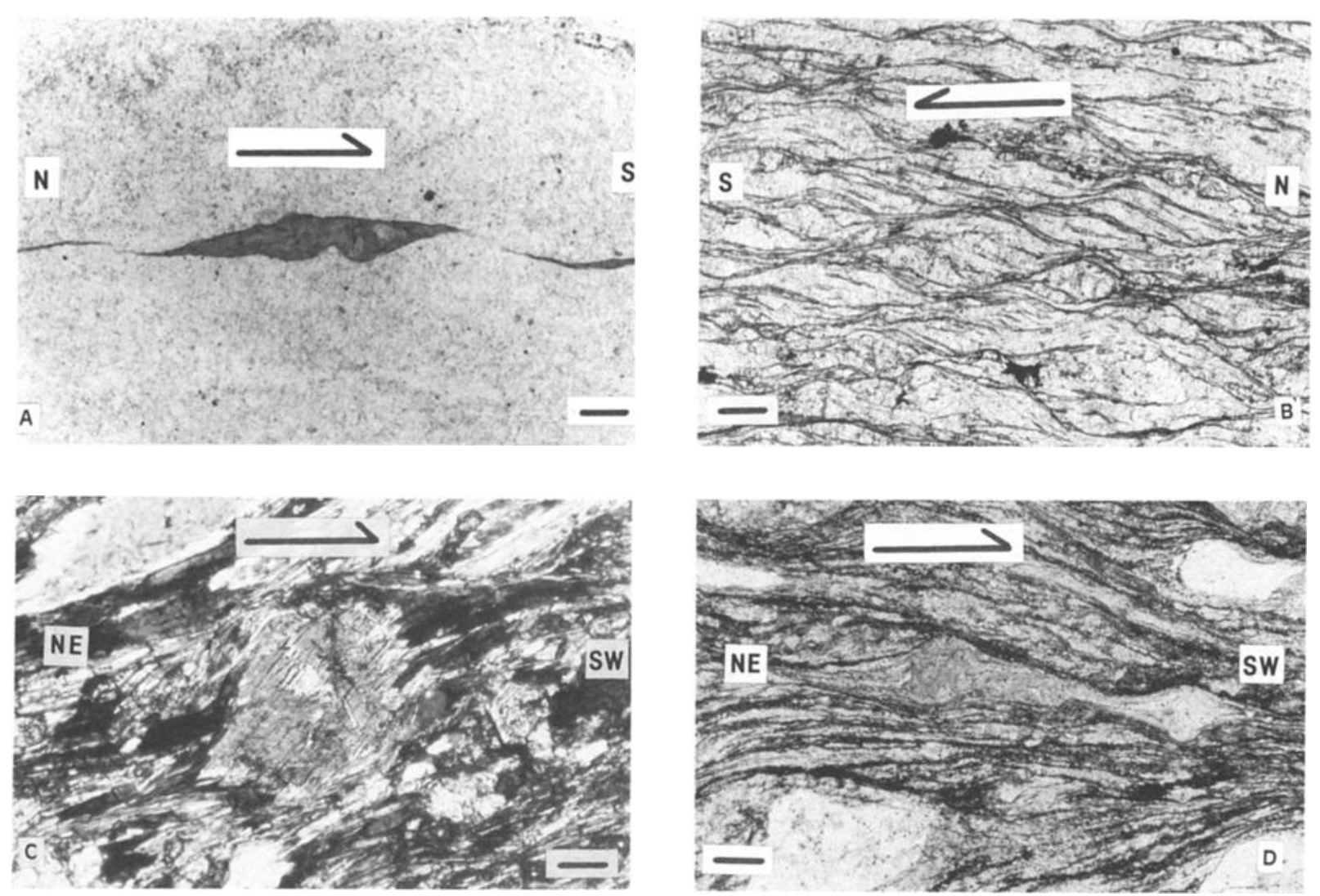

Fig. 9. Microscopic shear criteria in Romblon-Sibuyan area, located on Figure 7. (a) Sigmoidal chlorite in quartz schist, Romblon. Scale bar $=1 \mathrm{~mm}$. (b) Shear bands in pelitic schist, Romblon. Scale bar $=1 \mathrm{~mm}$. (c) Hornblende with asymmetric chlorite pressure shadows in basic schist, Romblon. Scale bar $=0.5 \mathrm{~mm}$. (d) Shear bands in volcanoclastic rock, Sibuyan. Scale bar $=1 \mathrm{~mm}$.

A bulk southward shear is clear1y inferred in Sibuyan and Romblon (Figure 7). As already stated, the microstructures of south and east Tablas were formed during a high-temperature (HT) metamor phism. Therefore they are not related to thrusting. In east Tablas the shear criteria along a high-angle dipping foliation indicate an eastward motion of the upper part, while in south Tablas, where the foliation is on average subvertical, no shear sense has been observed. When the foliation is flat 1ying, the $N 120^{\circ} \mathrm{E}$ trending lineation is refolded by $N 70^{\circ} \mathrm{E}$ overturned folds, but no shear sense can be found.

In conclusion, two distinct domains belong to the Romblon metamorphics: a northern area interpreted as a stack of synmetamorphic thrust sheets, emplaced in ductile conditions from north to south, and a southern area where the thrust structure and related synmetamorphic deformation is erased by a thermal metamorphism, probably due to granitic intrusion.

\section{AN OUTLINE OF THE NORTH PALAWAN GEOLOGY}

\section{Field Observations}

Field observations in North Palawan lead us to consider the following lithostratigraphic and tectonic units (Figures 10 and 11). Though partly similar to previous divisions (Bureau of Mines, 1963, Bureau of Mines and Geosciences (BMG) 1981; United Nations, 1985; Raschka et al., 1985, Wolfart et al., 1986), they differ on some lithologic and stratigraphic attributions. Several small Neogene granitic rocks cross cut the flat lying formations of North Palawan. From 
top to bottom the following sequence is recognized.

An ophiolitic sheet composed of harzburgite, serpentinite, gabbro, pillow basalt, and pelagic sediments forms the uppermost unit. Locally, this unit has an amphibolite sole, and some micaschists,

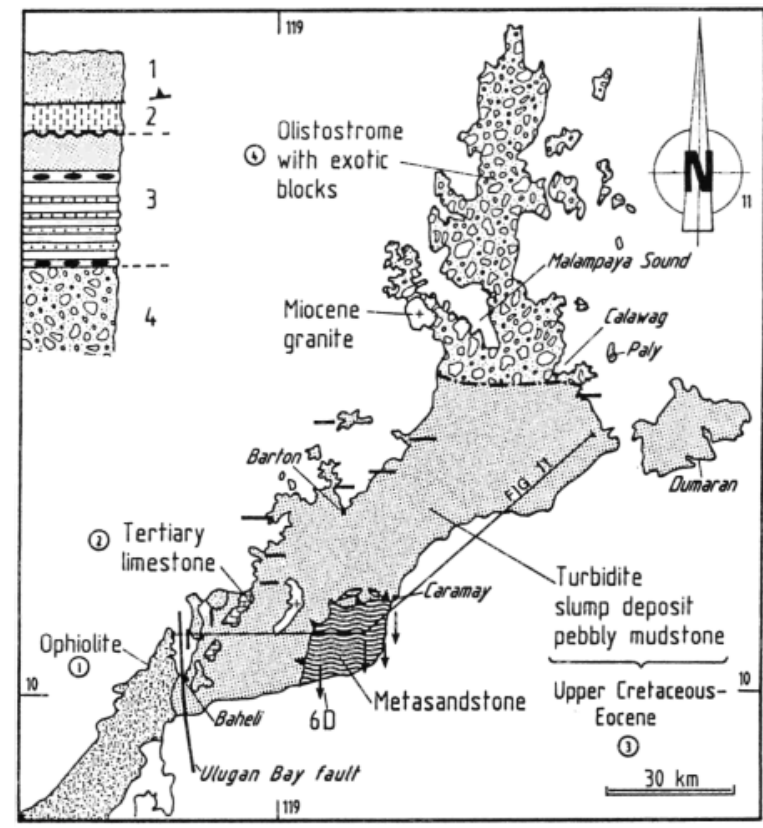

Fig. 10. Schematic structural map of North Palawan. E-W bars, Miocene stretching lineation without shear sense; N-S arrows, late Cretaceous stretching lineation showing southward movement of upper versus lower material.

Reinterpreted from Bureau of Mines (1963) and United Nations (1985). marbles, and quartzite are found at the base of the thrust. Early Cretaceous fossils have been found in cherts or red mudstones covering the volcanic rocks (Benard and Muller, 1986; BMG, unpublished data, 1988). The ophiolitic sheet thrusts a massive late Eocene to early Miocene reef limestone (St. Paul's, E1 Nido and Pabellon formations) which in turn unconformably overlies a clastic sequence.

This clastic sequence is the most widespread unit. Several facies such as turbidite, slump deposit, pebbly mudstone, and thick sandstone are recognized. The "Sagasa tectonic complex" (United Nations, 1985) is in fact formed by synsedimentary disrupted sandstone lenses and scarce chert and pillow lava olistoliths. An upper Cretaceous age is obtained from microfossils (Grellman and Newton, 1980; Saldivar-Sali et al., 1981; Wolfart et a1., 1986; Benard and Muller, 1986). The "Concepcion pebbly phyllite" and the "Tinitian creek conglomerate" (United Nations, 1985) are pebb1y mudstone formation. The northernmost end of Palawan was thought to represent the normal stratigraphic sequence of the Palawan Block, ranging from Permian to Jurassic (e.g., Hashimoto and Sato, 1973). However, sedimentological observations have shown that it is an olistostrome, bearing late Jurassic or ear1y Cretaceous radiolarians into the matrix (Faure and Ishida, 1989).

The lowermost unit is a metasandstone unit called the "Caramay schists" (United Nations, 1985). It consists of schistose sandstone and phyllite metamorphosed into greenschist facies conditions. The North Palawan area is often considered as extensively covered by the "Barton

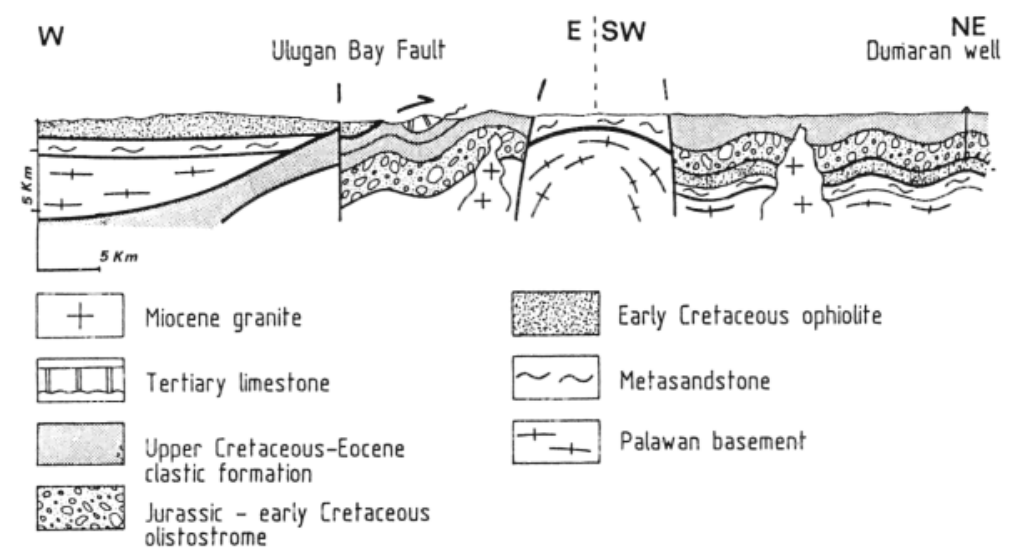

Fig. 11. Interpretative schematic cross section of North Palawan, along line shown in Figure 10. 
metamorphics" (Reyes 1941, in Bureau of Mines 1981). However, except for the Caramay schists and the amphibolite sole below the ophiolite, the North Palawan rocks do not seem to have experienced any metamorphism stronger than some epizonal recrystallization of phyllites.

Regional Structure of North Palawan and Thrust Rinematics

Hamilton 1979, Holloway 1982, Hinz and Schlüter (1985), and Mitchell et a1. (1986), suggest that the ophiolites overthrust the clastic sequence and probably the limestone. One interpretation is that this middle Miocene deformation is relevant of the "Mindoro collision" (Rangin et al. 1985; Marchadier, 1988). The conspicuous E-W trending lineation and microscopic shear criteria suggest a Miocene thrusting from west to east. This phase is a secondary one, an earlier ductile deformation is recognized both in the Caramay biotite schists and the amphibolite sole. It is characterized by a $\mathrm{N}-\mathrm{S}$ trending mineral and stretching lineation (L1) and isoclinal folds with axes parallel to L1. Asymmetric pressure shadows around quartz clasts indicate a southward shear (Figure 6d). This phase corresponds to the initial synmetamorphic thrusting from north to south of the ophiolitic sheet upon the Caramay schists. The fragments of micaschists and quartzites found below the amphibolite might be scrapped parts during the thrusting. Moreover, drilling hàs shown that around Dumaran and Paly islands (Figure 10) the olistostrome is underlain by serpentinized ultramafics (Grellman and Newton, 1980). These lines of evidence show that the structure of North Palawan, prior to the Miocene tectonics, corresponds to a similar stack of thrust sheets as observed in the Mindoro and Tablas areas (Figure 11).

\section{DISCUSSION AND INTERPRETATION}

Comparisons Between the Mindoro, Romblon, and Palawan Metamorphics

Several lines of evidence suggest that the Mindoro and Romblon metamorphics were formed during the same event. First, they contain the same 1ithological assemblages, namely the pelitic schistlimestone series of Puerto Galera and Romblon; basic schists of Mindoro, Lubang, Romblon, and Sibuyan, paragneisses of Mindoro, Lubang and Sibuyan. Second, with the exception of the anomalous HT area of SE Tablas, similar metamorphic conditions around $450^{\circ}-550^{\circ} \mathrm{C}$ and $4-5 \mathrm{kbar}$ are found in both areas. Third, the same regional stack of thrust sheets, olistostrome, ophiolite, and schist is observed. Finally, in both areas, the thrust displacement sense inferred from microtectonics is toward the south. Radiometric data in both areas are lacking. Another indirect piece of evidence is that the same early Miocene volcanic arc overlies both the Mindoro and Romblon metamorphics, showing that they have been put together at least at the end of Paleogene (Marchadier, 1988).

Resemblances are less clear between the Mindoro metamorphics and the metasandstone unit of Palawan. However, the same order of units and thrust vergence suggest that pre-Eocene deformation in both areas may belong to the same event.

\section{The Palawan Block}

Additional evidence that the Palawan and Mindoro-Romblon metamorphics belong to a single basement unit is the olistostrome. Though not explicitly recognized as olistostrome, this formation has been found in North Palawan (Faure and Ishida, 1989), Calamian (Fontaine, 1979; Fontaine et a1., 1979; Isozaki and Amiscaray, 1987), Buruanga peninsula (Fontaine et a1., 1983), Carabao and North Mindoro (M. Faure et al. unpublished data 1987). This olistostrome appears as a key formation for the recognition of the North Palawan Block of Hamilton (1979) and Holloway (1982). As the distributions of the olistostrome and metamorphics are overlapping in the study area, the combined use of these two formations allows us to enlarge the area of the North Palawan Block.

As a working hypothesis, we propose that the North Palawan Block can be extended to (1) South Palawan, since the Ulugan Bay fault (Figure 10) is a minor structure, and the same formations are found on both sides (Wolfart et al., 1986); (2) West Panay where early 
Cretaceous ophiolites and metamorphics are reported (Florendo, 1981; McCabe et al., 1982); and (3) Zamboanga area, where preEocene serpentinites, marbles, pelitic, and basic schists with submeridian lineations are described (Antonio, 1972).

\section{A Pre-Cenozoic Geodynamic Model}

In Palawan, Mindoro, and Romblon areas the pre-Eocene structure corresponds to a stack of thrust sheets formed by synmetamorphic thrusting of oceanic series (i.e., ophiolites and schists) above a continental basement. The nature (microcontinent, island arc, etc) and extension of this basement is not known exactly known, but it included at least Palawan, Mindoro, Romblon, and Zamboanga areas. We propose to call it the West Philippines Block. The thrusting occurred before Eocene and after ear1y Cretaceous, which is the age of the sedimentary part of the ophiolite. As this tectonism predates the 01igo-Miocene opening of the South China sea (Taylor and Hayes, 1983, Pautot et al., 1986), the ophiolites which are significantly older than the age of the South China Sea cannot be obducted parts of the South China Sea, and any geodynamic model must take into account the contemporaneous events occurring along the Chinese margin. Though the opening mechanism of the South China Sea is still disputed (e.g., Taylor and Hayes, 1983; Tapponnier et al., 1986; Ru and Pigott, 1986) if we close the South China Sea, the presently submeridian lineations keep the same trend or become close to NW-SE.

We propose the following scenario. During late Jurassic to early Cretaceous (Figures 12 and 13) an oceanic area was closing by subduction below Asia. Assuming that the thrusting direction inferred from lineations corresponds approximately to the plate motion vector at that time (e.g., Mattauer, 1975; Shackleton and Ries, 1984) the West Philippines Block moved from S-SE to NNE. At that time the South China margin is characterized by an voluminous calcalkaline magmatism. In Taiwan and along the $\mathrm{SE}$ coast of Fujian province, $\mathrm{Rb}-\mathrm{Sr}$ ages of granites range between 120 and 90 Ma (Jahn et a1., 1976). Very often there is a progressive transition from magmatically oriented granites to plastically deformed orthogneisses and mylonites. Mapping, microtectonic analysis, and strain studies show that the final emplacement of plutons initiated by subduction is related to the left-lateral strike-slip faults parallel to the continental margin ( $\mathrm{Xu}$ et al., 1987; J. Charvet and M. Faure unpublished data, 1988). A submeridian convergence oblique to the SE China margin is in agreement with the synchronous leftlateral displacement along the faults (Figure 13).

SE CHINA

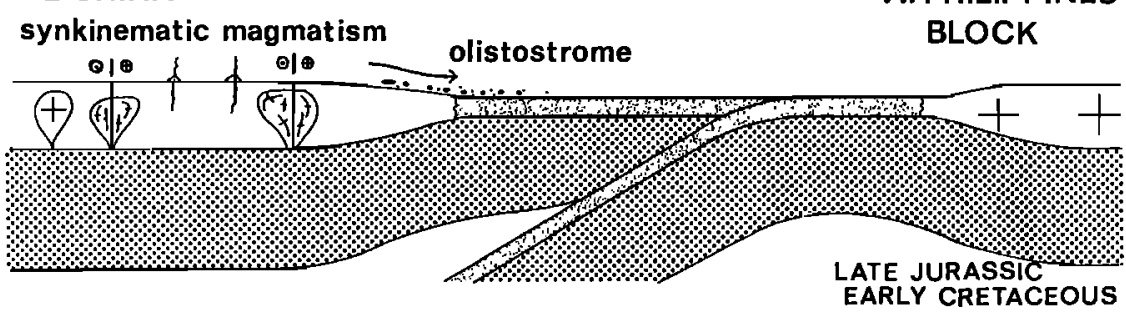

W. PHILIPPINES BLOCK

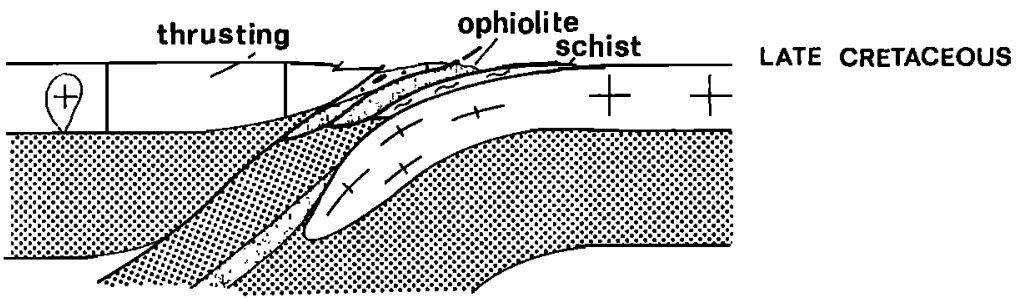

Fig. 12. Geodynamic evolution model of SE China-West Philippines area. 


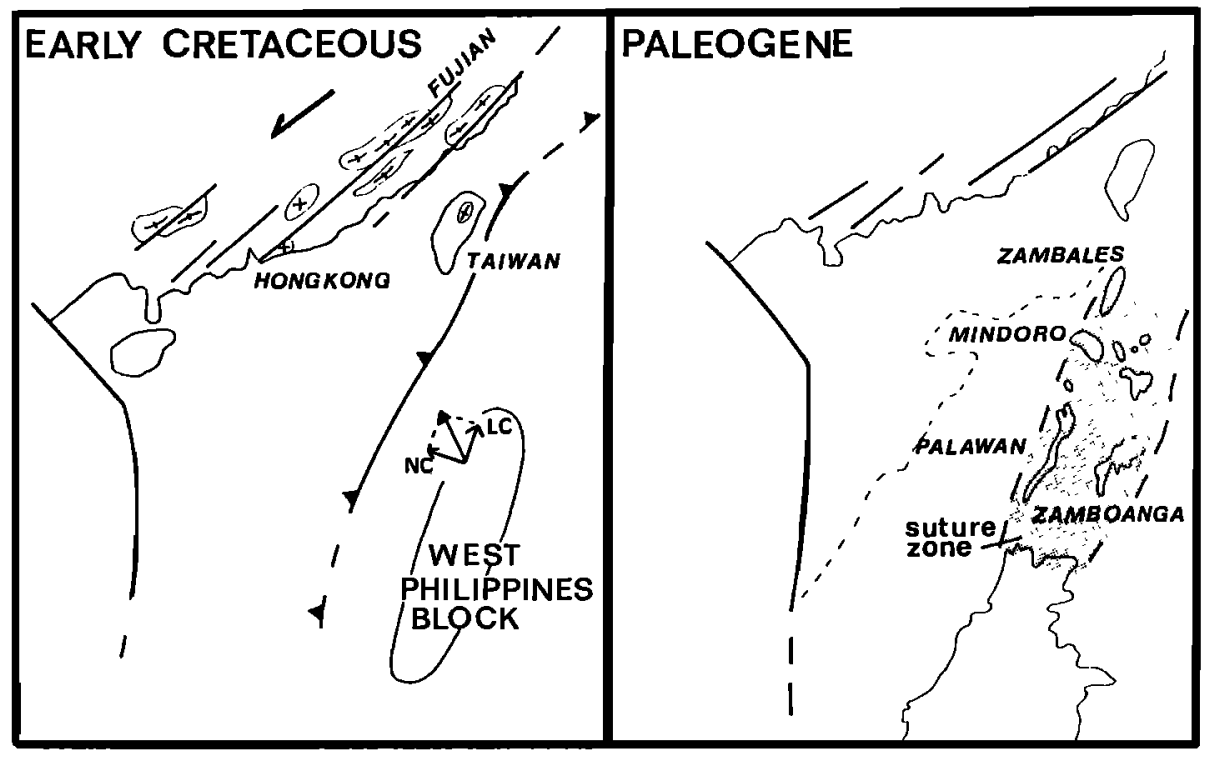

Fig. 13. Schematic tectonic map of the SE China-West Philippines area in pre-Eocene times. Early Cretaceous represents the oblique convergence stage. NC, normal component of subduction; LC, longitudinal component of subduction of the West Philippines Block with respect to Eurasia. Along the Chinese margin, left-lateral shearing and synkinematic magmatism occur. Paleogene shows that the collision is completed. A suture zone extends along the southeast China margin.

At the end of the late Cretaceous the continental subduction of the West Philippines Block leads to collision and stacking of thrust sheets upon the block. Southward thrusting also occurred in Hong Kong where the lower Cretaceous red beds (Port Island formation) are cleaved (e.g., Ruxton, 1956; M. Faure, unpublished data 1988) and in Fujian province ( $\mathrm{J}$. Charvet and $M$. Faure, unpublished data 1988). The nature of the Mesozoic SE China margin is commonly considered of Andean type, however according to this collisional model it has to be revised.

Acknowledgments. We are deeply indebted to G. Balce, R. Quebral, J. A. Magpantay and all their colleagues from the Bureau of Mines and Geosciences for their kind welcome and efficient support during our fieldwork in the Philippines. $\mathrm{J}$. Butterlin identified the foramminifera from Lubang island. R. McCabe, Z. BenAvraham, and D. Sarewitz are thanked for their comments and advices on way to improve the manuscript. Reasearch was supported by grants from the CNRS-INSU and
IFP. This is the CNRS-INSU DBT programm contribution 90 .

\section{REFERENCES}

Andal, D. R., and N. L. Caagusan, Geology of the iron deposits of northern Mindoro, paper presented at the 2nd Geological Convention, Geological Society of the Philippines, Manila,109$120,1968$.

Andal, D. R., J. S. Esguina, W. Hashimoto, B. P. Reyes, and T. Sato, The Jurassic Mansalay formation, southern Mindoro, Philippines, Geol. Paleonto1. Southeast Asia, 4, 179-197, 1968.

Antonio, L. R., Geology of the east -centra1 Zamboanga peninsula, Mindanao, 87 pp., Bureau of Mines and Geosciences, Manila, 1972.

Benard, F., and C. Mu1ler, Synthetic geological map obtained by remote sensing, an application to Palawan island, in Symposium on Remote Sensing for Resources Development, edited by M.C.J. Damen, G. Sicco Smit, and H.T. Verstappen, pp., 103-109, Balkema, Rotherdam, Netherlands, 1986. 
Bureau of Mines, Geological Map of the Philippines, scale 1/1000000, Manila, 1963.

Bureau of Mines and Geosciences, Geology and mineral resources of the Philippines, 406 pp., Manila, 1981.

Caagusan, N. L., Petrography of the metamorphic rocks of northern Mindoro, Bull. Inst. Filip. Geol., 1 , 22-46, 1966 .

Caculitan, P., D. Custodio, R. Rollan, and N. Ferrer, Report on the geological mapping and mineral canvassing of Abra de Ilog quadrangle, Mindoro, 9 pp., Bureau of Mines and Geosciences, Manila, 1978.

Cobbold, P., and H. Quinquis, Development of sheath folds in shear regimes, $J$. Struct. Geol., 2, 119-126, 1980.

Cobbold, P., D. Gapais, W.D. Means, and S.H. Treagus, editors, Shear criteria in rocks, J. Struct. Geol., 9, 778 pp., 1987.

Eisbacher, G. H., Deformation mechanics of mylonitic rocks and fractured granites in Cobequid Mountains, Nova Scotia, Canada, Geol Soc. Am. Bull., 81, 2009-2020, 1970 .

Escher, A., and J. Watterson, Stretching fabrics, folds and crustal shortening, Tectonophysics, 22, 223-231, 1974.

Etchecopar, A., A plane kinematic model of progressive deformation in a polycrystalline aggregate, Tectonophysics, 39, 121-139, 1977.

Faure, M., and K. Ishida, The Middle-late Jurassic olistostrome of West Philippines: a distinctive key formation for the North Palawan Block, $\mathrm{J}$. Southeast Asia Earth Sci. in press, 1989.

Florendo, F. F., Preliminary report on the geology, geotectonic development and mineralization of western Panay, 36 pp., Bureau of Mines and Geosciences, Manila, 1981.

Fontaine, H., Note on the Geology of the Calamian islands, North Palawan, Philippines, CCOP News1., 6, 40-72, 1979.

Fontaine, H., L. Beauvais, C. Poumot, and D. Vachard, Données nouvelles sur le Mésozoique de 1 'ouest des Philippines, Découverte de Rhetien marin, C. R. Somm. Soc. Geo1. France, 31, 1) $\overline{17-121}$, 1979 .

Fontaine, H., P. David, and N. Tien, A note on the northwest Panay-Tablas area, CCOP News1. 10, 8-13, 1983.

Gervasio, F. C., Age and nature of orogenesis of the Philippines, Tectonophysics, 4, 379-402, 1967.

Grellman, D. B., and S. T. Newton, Palawan Citco Dumaran 1, Final well report, 458 pp., Bureau of Energy Development, Manila, 1980.

Hamilton, W., Tectonics of the Indonesian region, U.S. Geol. Surv. Prof. pap. 1078, 345 pp., 1979.

Hashimoto, W., Geological development of the Philippines, Geol. Paleontol. Southeast Asia, 22, 83-170, 1981 .

Hashimoto, W., and T. Sato, Contribution to the geology of Mindoro and neighboring islands, the Philippines, Geo1. Paleonto1. Southeast Asia, 5, 192$210,1968$.

Hashimoto, W., and T. Sato, Geological structure of North Palawan, and its bearing on the geological history of the Philippines, Geol. Paleontol. Southeast Asia, 13, 145-161, 1973.

Hinz, K., and U. Schlüter, Geology of the Dangerous Grounds, South China Sea, and the continental margin off Southwest Palawan: Results of Sonne Cruises SO 23 and SO 27, Energy, 10, 297-315, 1985.

Holloway, N. H., North Palawan block, Philippines, Its relation to Asian mainland and role in evolution of South China Sea, Am. Assoc. Pet. Geol. Bull., $66,1355-1383,1982$.

Irwing, E.M., Review of Philippine basement geology and its problems, Philip. J. Sci., 79, 267-307, 1950.

Isozaki, Y., and E. Amiscaray, Middle Triassic-early Jurassic bedded radiolarian cherts in the Calamian islands, paper presented at International Geological Correlation Programm 224 meeting, Seoul, 20-30 August, 1987.

Jahn, B.M., P.Y. Chen, and T.P. Yen, $\mathrm{Rb}-\mathrm{Sr}$ ages of granitic rocks in southeastern China and their tectonic significance, Geol. Soc. Am. Bu11., 86, 763-776, 1976.

Karig, D. E., Accreted terranes in the northern part of the Philippine archipelago, Tectonics, 2, 211-236, 1983.

Knittel, U., and U. Daniels, Sr-isotopic composition of marbles from the Puerto Galera area (Mindoro, Philippines): Additional evidence for a Paleozoic age of a metamorphic complex in the Philippine island arc, Geology, 15, 136$138,1987$.

Malavieille, J., R. Lacassin, and M. 
Mattauer, Signification tectonique des lineations d'allongement dans les Alpes occidentales, Bull. Soc. Geol. Fr. 26, 895-906, 1984.

Malicse, J.A., and G. Yumul, Geology of the exposed ophiolite and surrounding rocks in Puerto Galera area, Mindoro, $10 \mathrm{pp}$. , Bureau of Mines and Geosciences, Manila, 1986.

Marchadier, Y., La terminaison de $1 a$ fosse de Manille en domaine continental. Etude stratigraphique et tectonique des iles de Mindoro-Tablas (Philippines), Thèse de doctorat, 367 pp., Univ . of Paris VI, 1988.

Mattauer, M., Sur le mécanisme de formation de la schistosité dans 1 'Himalaya, Earth Planet. Sci. Lett., 28, 144-154, 1975.

Mattauer, M., M. Faure, and J. Malavieille, Transverse 1ineation and large scale structures related to alpine obduction in Corsica, J. Struct. Geol., 3, 401-409, 1981 .

McCabe, R., J. Almasco, and W. Diegor, Geologic and paleomagnetic evidence for a possible Miocene collision in Western Panay, Central Philippines, Geology, 10, 325-329, 1982 .

McCabe, R., J. Almasco, and G. Yumul, Terranes of the Central Philippines in Tectonostratigraphic Terranes of CircumPacific Region, Circum-Pacific Energy and Mineral Resources, Earth Sci. Ser., vol. 1, edited by D.G. Howe11,pp., 421436, Circum-Pacific Council for Energy and Mineral Resources, Houston, Texas, 1985.

Meta1 Mining Agency, Report on geologica1 survey of Mindoro Island, $76 \mathrm{pp}$., Jpn. Int. Coop. Agency, Tokyo, 1983.

Mitche11, A.H.G., F. Fernandez, and A.P. de la Cruz, Cenozoic evolution of the Philippine archipelago, J. Southeast Asia Earth Sci., 1, 3-22, 1986.

Passchier, C., and C. Simpson, Porphyroclast systems as kinematic indicators, J. Struct. Geol., 8, 831$843,1986$.

Pautot, G., et al., Spreading direction in the Central South China Sea, Nature, $321,150-154,1986$.

Platt, J., and R. Vissers, Extensional structures in anisotropic rocks, J. Struct. Geol., 2, 397-410, 1980.

Rangin, C., J. F. Stephan, and C. Muller, Jammed South China Middle Oligocene oceanic crust into Mindoro collision zone (Philippines), Geology, 13, 425428, 1985.

Raschka, H., E. Nacario, D. Rammlmair, C. Samonte, and L. Steiner, Geology of the ophiolite of Central Palawan island, Philippines, Ophioliti, 10, 375-390, 1985.

Ru, K., and J. Pigott, Episodic rifting and subsidence in the South China Sea, Am. Assoc. Pet. Geol. Bul1. 70, 11361155, 1986.

Ruxton, B., The Geology of Hong Kong, Q. J. Geol. Soc. London, 115, 233-261, 1956 .

Saldivar-Sali, A., H. G. Oersterle, and D. N. Brownlee, Geology of offshore northwest Palawan, Philippines, Oil Gas J., 79, 120-128, 1981 .

Sarewitz, D., and D. Karig, Processes of allochtonous terrane evolution, Mindoro island, Philippines, Tectonics, 5, 525552, 1986.

Sato, T., Les ammonites oxfordiennes de 1'ile de Mindoro, Philippines, Jpn. J. Geo1. Geogr. , 32, 141-143, 1961 .

Shackleton, R.M., and A.C. Ries, The relation between regiona11y consistent stretching lineation and plate motion, J. Struct. Geol. , 6, 111-117, 1984 .

Simpson, C., and S. Schmid, An evaluation of criteria to deduce the sense of movement in sheared rocks, Geo1. Soc. Am. Bu11., 94, 1281-1288, 1983.

Stephan, J. F., R. Blanchet, C. Rangin, B., Pelletier, J. Letouzey, and C. Muller, Geodynamic evolution of the Taiwan-Luzon -Mindoro belt since the late Eocene, Tectonophysics, 125, 245268, 1986.

Tapponnier, P., G. Peltzer, and A.Y. Le Dain, On the mechanics of the collision between India and Asia, in Collision Tectonics, edited by M.P. Coward and A.C. Ries, pp., 115-157, Geological Society Spec. Pub1. 19, London, 1986.

Taylor, B., and D. E. Hayes, The origin and history of the South China basin, in The Tectonic and Geologic Evolution of Southeast Asian Seas and Islands, 2, Geophys. Monogr. Ser., vol. 27, edited by D. E. Hayes, pp.23-56, AGU, Washington, D. C., 1983.

Teves, J. S., The pre-Tertiary geology of southern oriental Mindoro, Philipp. Geo1., 8, 1-36, 1953.

United Nations, Geology of Central Palawan, Tech. Rep. 6, 45 pp., United 
Nations Development Program, New York, 1985.

Wolfart, R., P. Cepek, F. Gramann, E. Kemper, and H. Porth, Stratigraphy of Palawan island, Philippines, News1. Stratigr., 16, 19-48, 1986.

$\mathrm{Xu}$, J., G. Zhu, W. Tong, K. Cui, and Q. Liu, Formation and evolution of the Tancheng-Lujiang wrench fault system: a major shear system to the northwest of the Pacific ocean, Tectonophysics, 134, 273-310, 1987.
M. Faure, CNRS URA 1366, Département des Sciences de la Terre, Université d'Orléans, B.P. 6759 Orléans Cedex 2, France.

Y. Marchadier and C. Rangin, Département de Géotectonique, Université Pierre et Marie Curie, Paris VI, France.

(Received October 26, 1988; revised March 13, 1989, accepted April 5, 1989.) 